\title{
Article \\ Sound-Absorbing Composites with Rubber Crumb from Used Tires
}

\author{
Olga M. Smirnova ${ }^{1, * \mathbb{D}}$, Ignacio Menéndez Pidal de Navascués ${ }^{2} \mathbb{D}$, Vladislav R. Mikhailevskii ${ }^{1}$, Oleg I. Kolosov $^{1}$ \\ and Nikita S. Skolota ${ }^{1}$
}

1 Department of Constructing Mining Enterprises and Underground Structures, Saint-Petersburg Mining University, 21-st Line V.O., 2, 199106 Saint-Petersburg, Russia; vladislavmikhailevskii@gmail.com (V.R.M.); koi2001@ya.ru (O.I.K.); nikita6578@mail.ru (N.S.S.)

2 Laboratorio de Geología, Departamento de Ingeniería y Morfología del Terreno, Universidad Politécnica de Madrid, 28040 Madrid, Spain; ignacio.menendezpidal@upm.es

* Correspondence: smirnovaolgam@rambler.ru

Citation: Smirnova, O.M.; Menéndez Pidal de Navascués, I.; Mikhailevskii, V.R.; Kolosov, O.I.; Skolota, N.S. Sound-Absorbing Composites with Rubber Crumb from Used Tires. Appl. Sci. 2021, 11, 7347. https://doi.org/ 10.3390/app11167347

Academic Editor:

Joan Formosa Mitjans

Received: 23 May 2021

Accepted: 27 July 2021

Published: 10 August 2021

Publisher's Note: MDPI stays neutral with regard to jurisdictional claims in published maps and institutional affiliations.

Copyright: (c) 2021 by the authors. Licensee MDPI, Basel, Switzerland. This article is an open access article distributed under the terms and conditions of the Creative Commons Attribution (CC BY) license (https:/ / creativecommons.org/licenses/by/ $4.0 /)$.

\begin{abstract}
Traditional sound-absorbing materials have a number of disadvantages: low water resistance, low compressive and tensile strengths, low weather resistance, etc. Therefore, new soundabsorbing materials need to be developed with improved properties including the involvement of industrial byproducts. The influence of the grain-size composition of the rubber crumb from used car tires on the sound insulation of cement and gypsum composites was studied in the paper. The results of the study contribute to the creation of a structural material for the manufacture of soundabsorbing as well as load-bearing structures. The field of application of the developed materials is very extensive.
\end{abstract}

Keywords: resource-saving technologies; gypsum-cement-pozzolan composition; fine aggregate; sound-absorbing material

\section{Introduction}

Sound is a physical phenomenon generated by the oscillatory movements of medium particles. Sound spreads well in air and is quite often a cause for concern for many people. People use sound-insulating and sound-absorbing materials for finishing rooms in which they are located in order to protect themselves from loud sounds. Sound-absorbing materials are also used to protect residential areas from high-speed highways [1-3].

One of the classifications of acoustic materials is shown in Figure 1.

Traditional acoustic materials have a number of disadvantages: low water resistance; low compression and bending strength; high compressibility; and low weather resistance [4-6]. There is a need to develop new acoustic materials with the above-mentioned properties improved, including the involvement of natural materials [7-9], industrial byproducts and secondary resources [10-13]. This can be achieved by using cement and gypsum composites with appropriate structures and porosities [14-16]. The necessary porosity, namely porosity with interconnecting pores, can be created by using the rubber crumb from used car tires.

Cement concrete with fine and coarse aggregates based on rubber crumb from used car tires can have good sound-absorbing properties according to published data [17-19]. In addition, sound-absorbing cement composites can reduce the cost of walls by eliminating sound-absorbing layers, for example, based on polymer materials, as well as reduce the construction duration. There will be additional room for designers in the field of urban and industrial to creatively design constructions including technologies that make use of 3D-printed concrete [20,21]. 


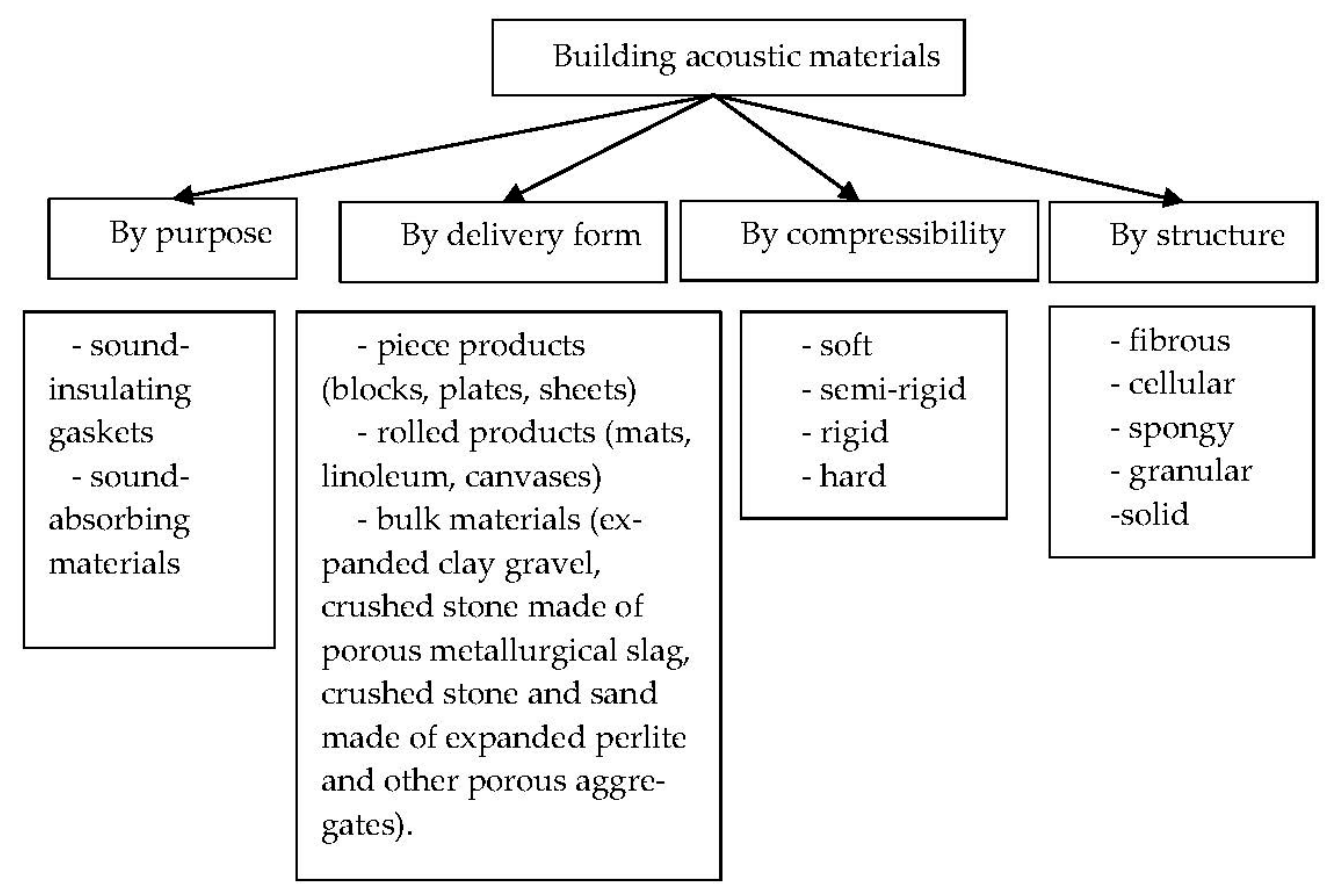

Figure 1. Classification of acoustic materials.

The production of sound-absorbing concrete based on inorganic binders is possible according to the technology of monolithic concreting and prefabricated concrete products manufactured at plants. It is also possible to use a sound-absorbing plaster layer on the surface of a material that was not previously provided with sound insulation. Possible combinations of sound-absorbing plaster and base material are shown in Figure 2.

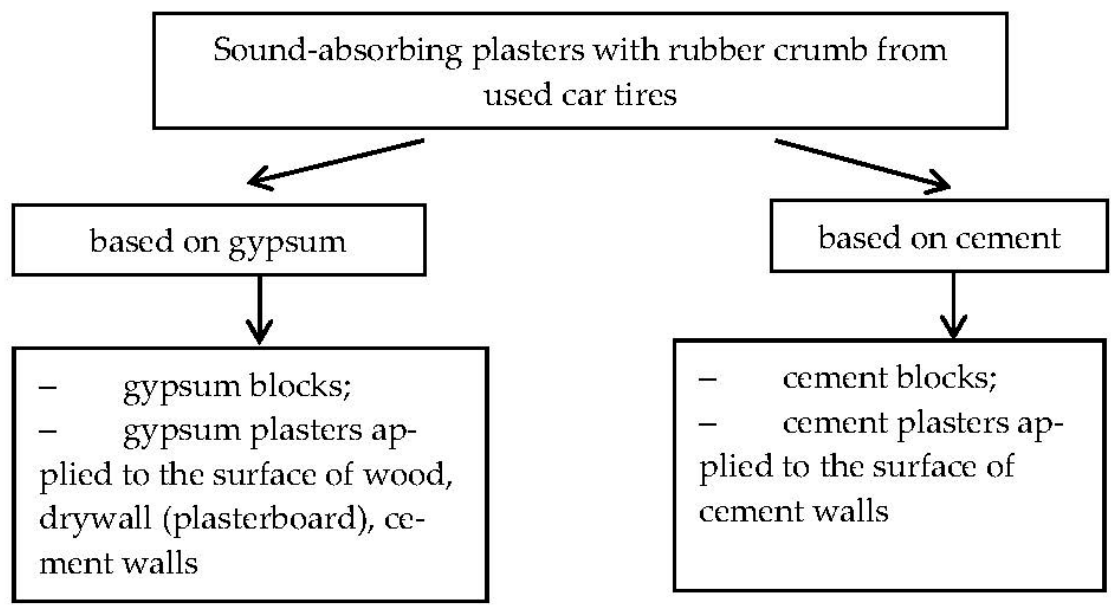

Figure 2. Possible combinations of sound-absorbing plaster and base material.

New sound-absorbing composites can be found in use as enclosing structures on high-speed highways as well as in industrial and residential neighborhoods.

One advantage of the new sound-absorbing composites from the point of view of ecology is the possibility of the utilization of multiple tons of waste rubber products [22,23]. Recently, rubber crumb made from used tires has been increasingly used in various composite materials and structures [24-26].

Sound-insulating and sound-absorbing materials work according to the principle of the passive reduction in the amplitude of sound oscillations due to their structure and thickness [27-29]. Creating the structure of a material with a certain porosity is the main direction of research in the development of acoustic materials [30-32]. 
Acoustic materials may have a certain porosity that can be achieved by regulating the quantity and grain composition of the rubber crumb. A sound-absorbing material is a material that has interconnected pores and a relatively high sound absorption coefficient $(\alpha>0.2)$, which is equal to the ratio of the non-transmitted flow of sound energy through the material to the falling flow of the sound energy on the material or product. The main requirement for sound-absorbing materials is to produce these materials as precast concrete elements or as elements intended for use in sound-absorbing structures.

At present the number of production facilities for processing tires into rubber crumb is increasing [33-35]. However, published data on the effect of the grain-size composition of rubber crumb on the sound-absorbing properties of cement and gypsum composites are not sufficient and therefore require additional research. Rubber crumb has good adhesion with cement and gypsum matrices, including the cement matrices based on secondary resources [36-38], which should contribute to obtaining the adequate strength characteristics.

The aim of the paper is to study the effect of the grain-size composition of the rubber crumb from the used tires on the sound-absorbing coefficient of the composites and on the strength properties. The results of the study contribute to the creation of structural material for the manufacture of sound-absorbing as well as load-bearing structures. The field of application of the developed material is very extensive. This material is suitable for producing sound-absorbing, load-bearing and self-supporting structures which can be used in different applications depending on their final sound-absorbing as well as physical and mechanical properties.

By changing the type of binder, the amount of gypsum or cement and rubber crumb it is possible to adjust the properties of the acoustic material in a wide range, including such properties as water resistance, compressive and bending strength, and sound absorption coefficient.

\section{Technologies of Making the Rubber Crumb}

In practice two main methods of producing rubber crumb are used: the shock and wave method and the mechanical method $[39,40]$.

The shock and wave method of grinding automobile tires and other rubber waste into crumb was invented relatively recently. The process consists in cooling the tires to ultralow temperatures followed by crushing with a shock wave. Such technology of processing worn-out automobile tires requires the installation of expensive equipment, which is economically profitable only for large enterprises with large volumes of raw materials.

The mechanical method is a classic technology of processing tires into rubber crumb, which is used everywhere, unlike the abovementioned one. The essence of the process is a step-by-step mechanical tire processing obtaining the required fraction of rubber crumb and byproducts. There are several methods of mechanical tire processing: grinding under normal temperature conditions; at high temperature; with cooling of raw materials; using an "ozone knife"; pushing the raw material with a powerful press through special matrices, etc.

\section{Materials and Methods of Research}

\subsection{Material Characteristics}

Two types of composites based on inorganic binders were studied: gypsum-cementpozzolan binder and Portland cement.

The material based on gypsum-cement-pozzolan binder includes the following components:

1. Semi-aqueous gypsum of the G5BII brand produced by JSC "Samara Gypsum Plant" in accordance with the Russian standard 125-2018;

2. Portland cement CEM I 42.5 in accordance with the Russian standard 31108-2016;

3. pozzolanic additive-metakaolin in accordance with the Technical Specifications 5729-098-12615988-2013;

4. Tap water in accordance with the Russian standard 23732; 
5. Superplasticizer Melment F15G, which is a sulfonated powder product based on melamine. The additive is used to increase the workability and reduce the water demand of gypsum paste based on semi-aqueous gypsum. The additive meets the requirements of the Russian standard 24211-2008;

6. Ground rubber crumb from used tires-in accordance with the Technical Specifications 2519-001-09691885-2016 "Rubber crumb".

The sieve analysis was used to determine the grain composition according to Table 1.

Table 1. Grain composition of rubber crumb.

\begin{tabular}{|c|c|c|c|c|c|c|c|c|}
\hline \multirow{2}{*}{ Grain Composition } & \multirow{2}{*}{ Residue on the Sieve } & \multicolumn{6}{|c|}{ Residue on the Sieve, $\%$ by Mass } & \multirow[t]{2}{*}{$\begin{array}{l}\text { Passage through the } \\
\text { Sieve No. } 016 \text { (Tray) }\end{array}$} \\
\hline & & 5 & 2.5 & 1.25 & 0.63 & 0.315 & 0.16 & \\
\hline \multirow{2}{*}{$\begin{array}{c}\text { Initial grain } \\
\text { composition No. } 1\end{array}$} & Particular, \% & 0 & 18.2 & 51.8 & 21.6 & 5.4 & 2 & 1 \\
\hline & Total, \% & 0 & 18.2 & 70 & 91.6 & 97 & 99 & 100 \\
\hline \multirow{2}{*}{$\begin{array}{c}\text { Improved grain } \\
\text { composition No. } 2\end{array}$} & Particular, $\%$ & 0 & 6 & 29 & 29 & 28 & 7 & 1 \\
\hline & Total, \% & 0 & 6 & 35 & 64 & 92 & 99 & 100 \\
\hline
\end{tabular}

The size modulus of rubber crumb No. 1 can be calculated:

$$
M_{k}=\frac{18.2+70+91.6+97+99}{100}=3.6
$$

The size modulus of rubber crumb No. 2 can be calculated:

$$
M_{k}=\frac{6+35+64+92+99}{100}=2.96
$$

The rubber crumb of both grain compositions can be attributed to a fine aggregate of increased fineness in terms of the size modulus as shown in Figure 3.

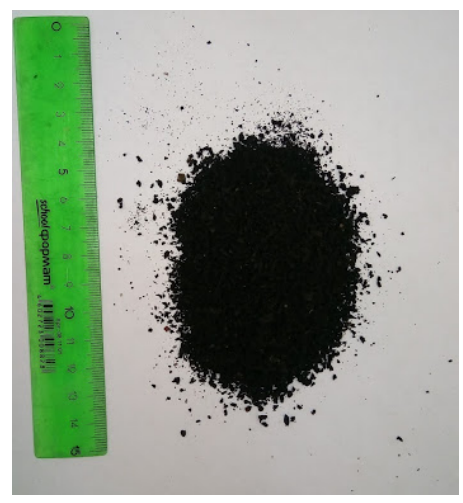

Figure 3. Rubber crumb of improved grain composition No. 2.

The compositions of the cement mortar are shown in Table 2.

A sample of rubber crumb-based cement composite obtained is shown in Figure 4.

It can be assumed that the rubber crumb due to its large specific surface will increase the water demand of the mixture or will reduce the workability of the mixture. This can lead to a decrease in strength. Accordingly, a superplasticizer is added to the compositions to improve the workability of the fresh mixture.

The tile samples were made to evaluate the sound-absorbing properties of the gypsumcement-pozzolan composition for plasters (Figure 5). The samples were made as follows: the needed amount of water is poured into a working mixer and then the superplasticizer is added to the water and mixed. Further, the Portland cement, semi-aqueous gypsum, metakaolin and rubber crumb are added and mixed. 
Table 2. Compositions of mortars based on Portland cement.

\begin{tabular}{cccccccc}
\hline Composition Number & $\mathbf{1}$ & $\mathbf{2}$ & $\mathbf{3}$ & $\mathbf{4}$ & $\mathbf{5}$ & $\mathbf{6}$ \\
& & No Rubber Crumb & \multicolumn{2}{c}{$\begin{array}{c}\text { Rubber Crumb of Initial Grain } \\
\text { Composition No. 1, \% of Sand Mass }\end{array}$} & $\begin{array}{c}\text { Rubber Crumb of Improved Grain } \\
\text { Composition No. 2, \% of Sand Mass }\end{array}$ \\
\cline { 3 - 8 } & & $\mathbf{5}$ & $\mathbf{1 0}$ & $\mathbf{1 0 0}$ & $\mathbf{5}$ & $\mathbf{1 0}$ & $\mathbf{1 0 0}$ \\
\hline Portland cement, g & 700 & 700 & 700 & 700 & 700 & 700 & 700 \\
Sand, g & 1400 & 1330 & 1260 & 0 & 1330 & 1260 & 320 \\
Water, g & 320 & 320 & 320 & 350 & 320 & 350 \\
Superplasticizer 1.8\%, g & 12.6 & 12.6 & 12.6 & 12.6 & 12.6 & 12.6 & 12.6 \\
Rubber crumb, g & 0 & 70 & 140 & 320 & 70 & 140 \\
\hline
\end{tabular}

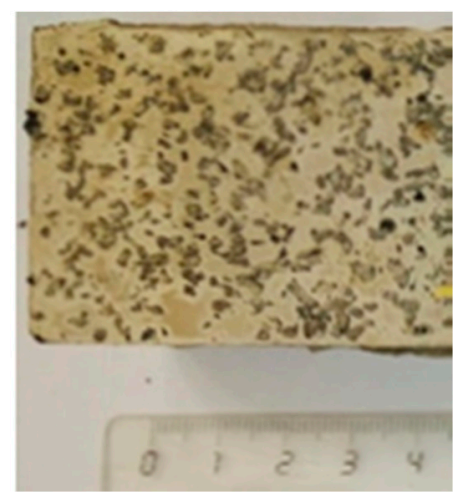

Figure 4. Macrostructure of cement composite with rubber crumb.
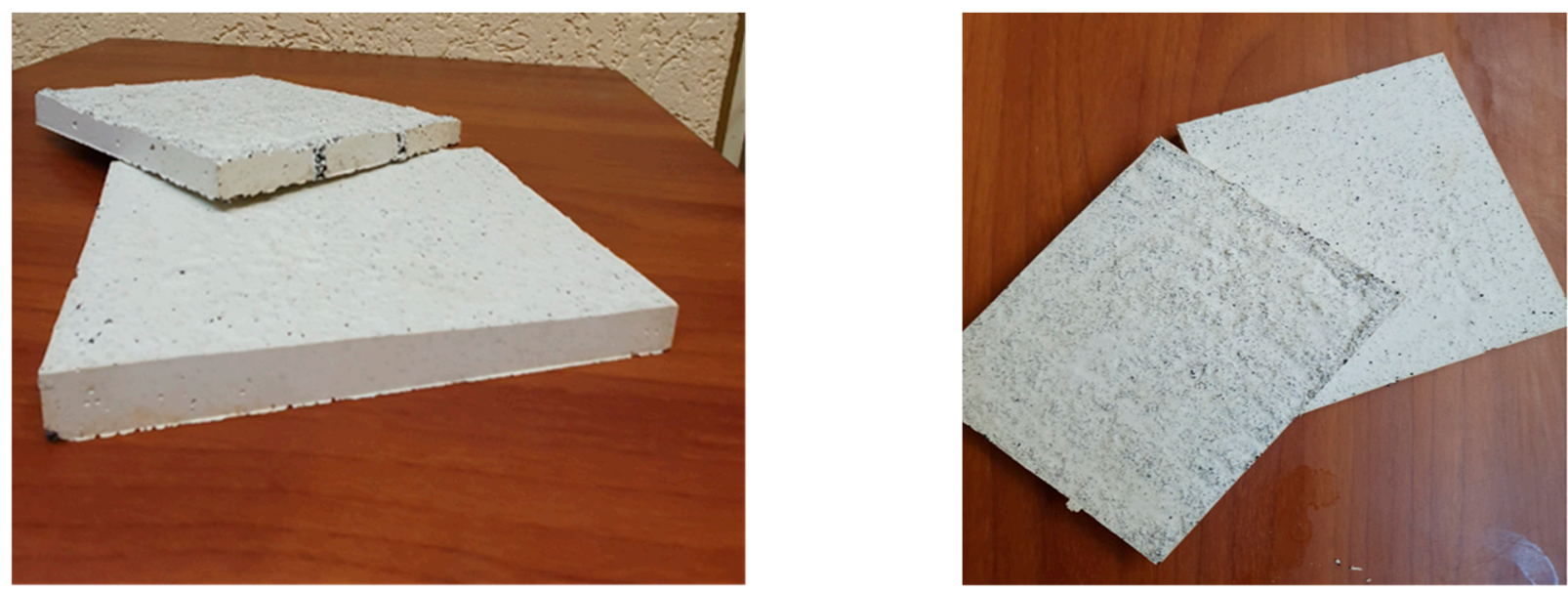

Figure 5. Tiles with rubber crumb (side and top view).

\subsection{Testing Method}

The compression and bending tests were performed on a combined testing machine with the measurement results presented in digital form. For this purpose the prism samples with dimensions of $40 \times 40 \times 160 \mathrm{~mm}$ were prepared and tested according to the standard procedure.

A stand was assembled for comparing the sound-absorbing properties of pure cement or gypsum composites and composites with the addition of rubber crumb. Its scheme is shown in Figure 6. This bench determined the sound absorption capacity of the $160 \times 160 \times 40 \mathrm{~mm}$ samples.

The body and the stand cover were made of a sound-absorbing material (foam). A device was placed into the stand to record the maximum noise level. A window was made in the stand body for mounting the test samples in. The constant sound source was at a constant distance from the test sample and the measurement time was $10 \mathrm{~s}$. The relative humidity was $55 \%$ and the ambient temperature was $20^{\circ} \mathrm{C}$. 


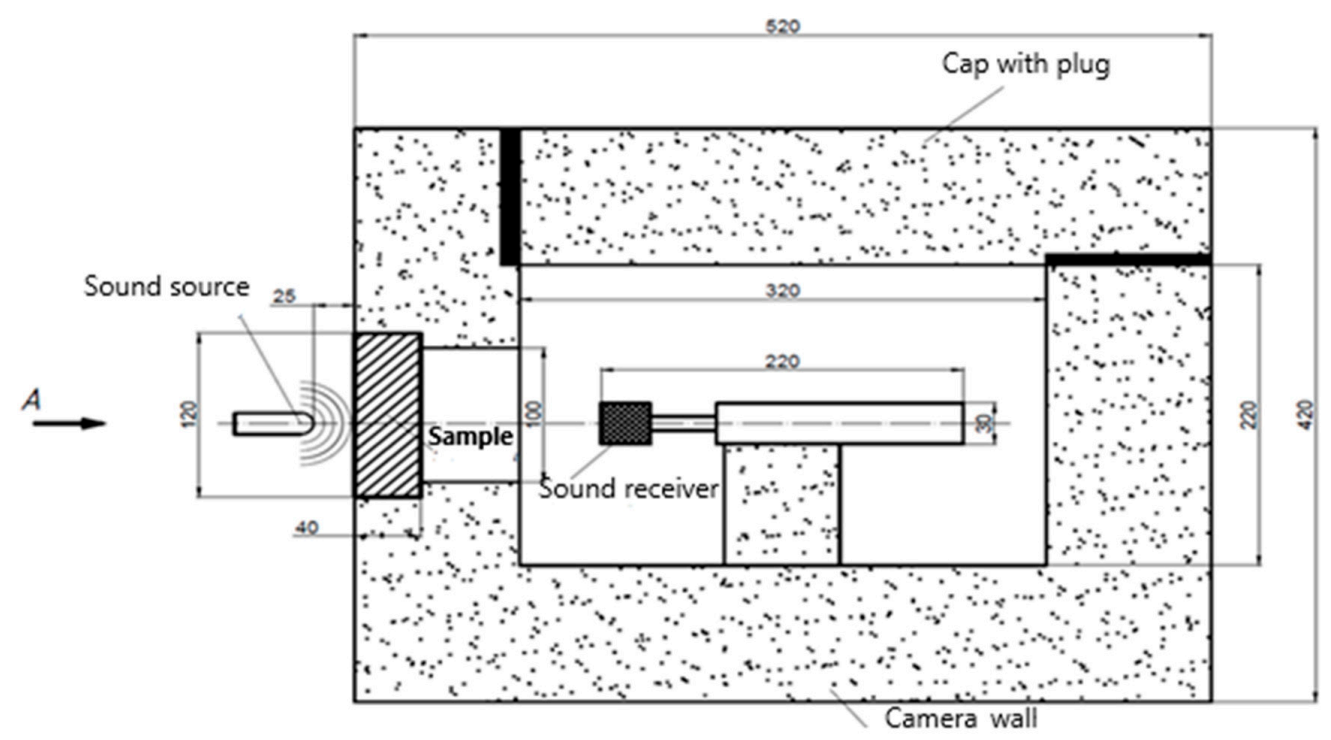

Figure 6. Schema of the sample test bench for sound absorption.

Sound-absorbing materials and products are characterized according to the Russian standard 23499-2009 "Materials and products of sound-insulating and sound-absorbing construction". The effect of grain composition and quantity of rubber crumb on the composite properties was studied. The sound absorption coefficient was calculated as the ratio of the amount of sound energy absorbed by the barrier to the energy falling on it. It is measured from 0 to 1 . The higher the coefficient value is, the greater the sound absorption.

\section{Results of Research and Testing}

\subsection{Strength Properties}

The effect of the amount of rubber crumbs on the workability of the mortar mixture is shown in Figure 7. The slump flow decreases with the increase in amount of rubber crumb of both grain compositions, but the rubber crumb of composition No. 2 reduces the slump flow to a lesser extent.

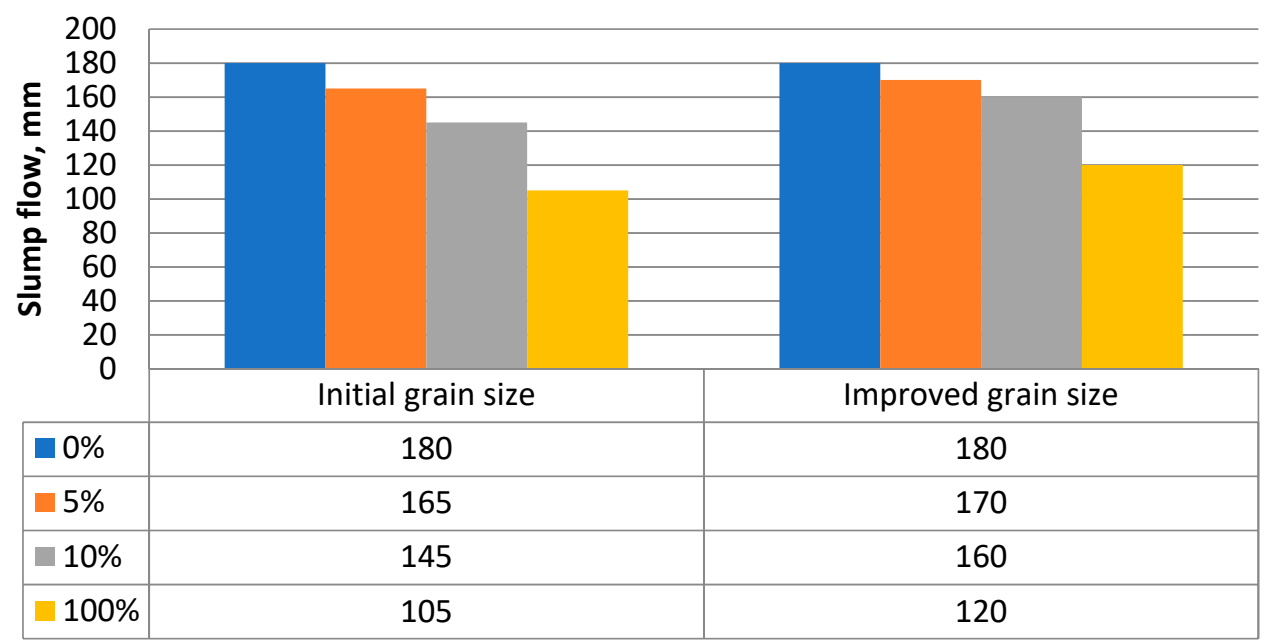

Figure 7. Effect of the rubber crumb on the workability of fresh mixtures.

The results of the influence of the grain composition and the quantity of crumbs on the tensile strength in bending and compressive strength are presented in Table 3.

When analyzing the results of Table 3 it can be seen that the value of compressive strength decreases with the increase in the amount of rubber crumbs. The character of the destruction of samples changes from brittle destruction to softening (Figure 8). It should 
also be noted that the improved grain composition has a positive effect on the strength characteristics of the samples. This can be explained by the good workability of mixtures with grain composition No. 2, which reduced the amount of mixing water. Reducing the water demand increases the strength of the cement matrix and the composite itself.

Table 3. Compressive strength and tensile strength in bending.

\begin{tabular}{cccccccc}
\hline Composition No. & $\mathbf{1}$ & $\mathbf{2}$ & $\mathbf{3}$ & $\mathbf{4}$ & $\mathbf{5}$ & $\mathbf{6}$ & $\mathbf{7}$ \\
\hline Tensile strength in bending, $\mathrm{MPa}$ & 7.79 & 5.84 & 6.51 & 1.4 & 6.68 & 6.81 & 1.6 \\
Compressive strength, MPa & 38.86 & 28.53 & 24.93 & 8.2 & 33.9 & 30.4 & 8.9 \\
\hline
\end{tabular}

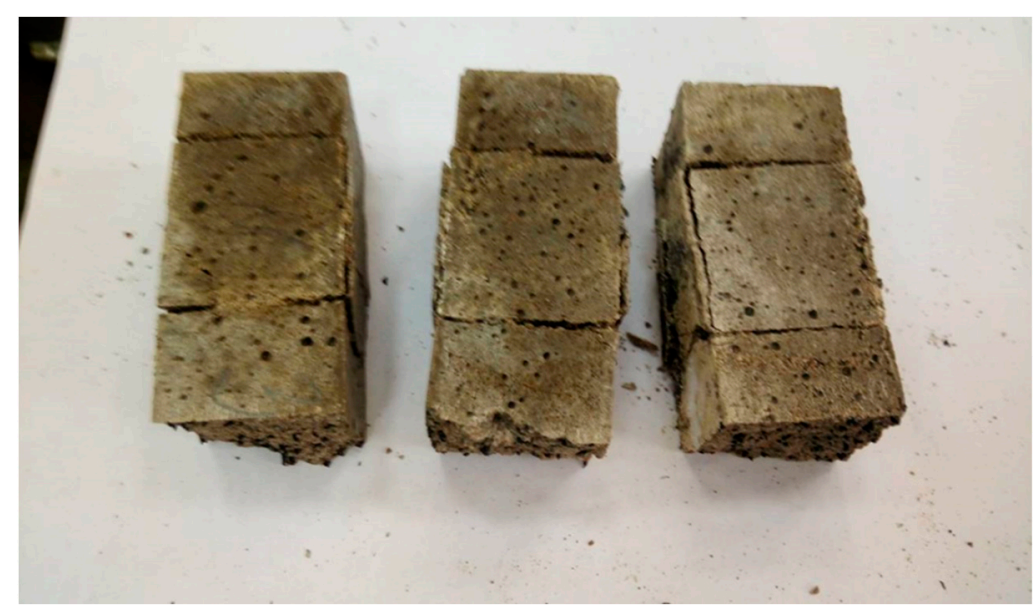

Figure 8. The character of destruction of samples with composition No. 5 (crumpling the concrete).

From the analysis of the results of Table 3 and Figure 9 it can be concluded that the rubber crumb in the amount of $5-10 \%$ of sand mass practically does not affect the value of the bending strength but the "stress-strain" curves for samples with crumb change significantly. The area under the stress-strain curve increases significantly for the samples with crumbs, which is associated with an increase in the work spent on the samples' destruction. This confirms the increase in the deformation properties of the new cement composites with rubber crumbs. This dependence (Figure 9) can be explained by the fact that the rubber crumb inside the sample does not allow the instant destruction of the sample after the appearance of the first crack, unlike the samples without the rubber crumb (red graph). The red graph shows the brittle destruction of the material.

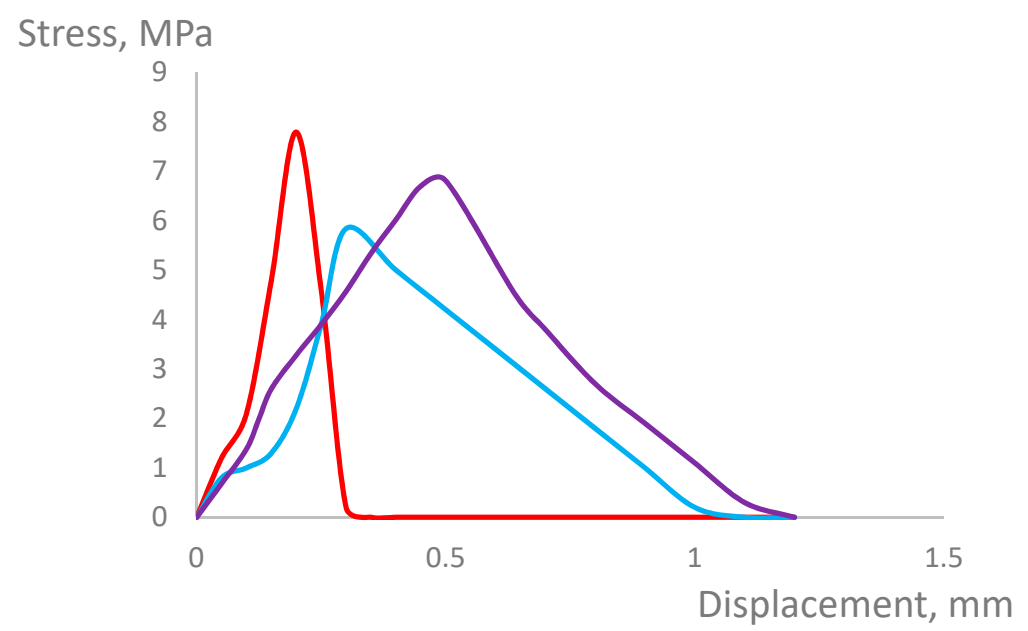

Figure 9. Deformation curves of samples during the bending stress test. 
The rubber crumbs inside the material stretch and do not allow the sample to collapse quickly. After the bending tensile tests, the samples with the rubber crumb had to be broken in half by hand since the crumb was well bonded to the cement matrix.

\subsection{Sound Absorption}

The quantitative dependences between the noise level after crossing the barrier and the rubber crumb amount were obtained from the results of testing the developed soundabsorbing composites. They are shown in Figure 10.

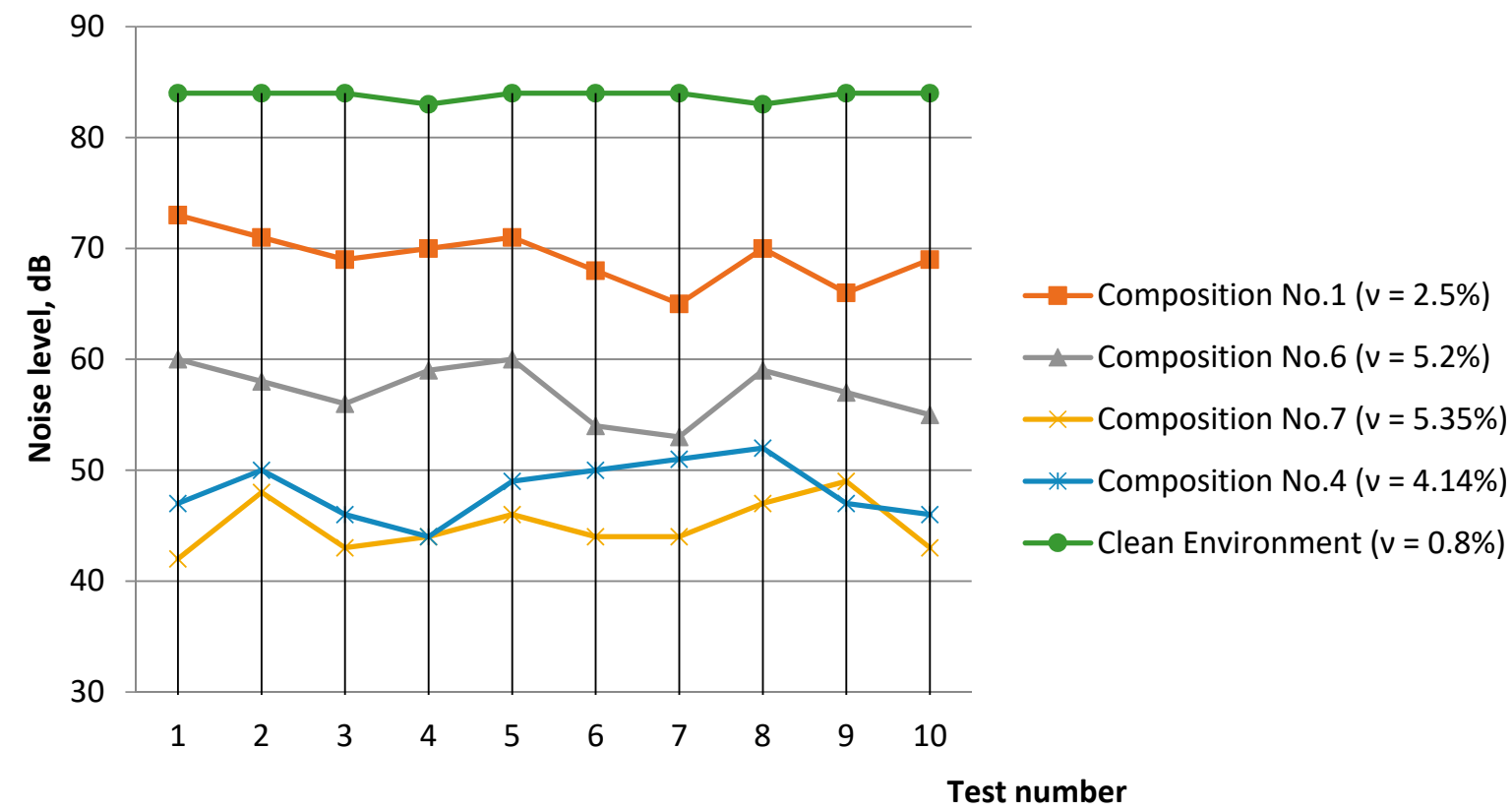

Figure 10. Results of the samples test for sound absorption ( $v$-coefficient of variation).

Three compositions with different amounts of rubber crumb were tested. The first control composition contained no rubber crumb, the sixth composition contained only rubber crumb as aggregate. The graph shows that the sound absorption capacity of the material increases as the rubber crumb quantity increases. The results of determining the coefficient of the sound absorption of the material are shown in Table 4.

Table 4. Sound absorption of developed composites.

\begin{tabular}{ccccc}
\hline Composition Number & $\begin{array}{c}\text { Percentage of Rubber } \\
\text { Crumb Amount } \\
\text { Relative to Aggregate }\end{array}$ & Initial Noise Level, dB & $\begin{array}{c}\text { Noise Level after } \\
\text { Crossing the Barrier, dB }\end{array}$ & $\begin{array}{c}\text { Coefficient of Sound } \\
\text { Absorption }\end{array}$ \\
\hline 1 & $0 \%$ & 83.80 & 69.2 & 0.17 \\
6 & $10 \%$ & 83.80 & 57.1 & 0.31 \\
7 & $100 \%$ & 83.80 & 45.0 & 0.46 \\
4 & $100 \%$ & 83.80 & 48.2 & 0.42 \\
\hline
\end{tabular}

One can conclude that the most effective in terms of sound absorbing properties is the composition of concrete using only rubber crumb as an aggregate. The result was achieved due to the addition of the fractioned rubber crumb of fractions from 5 to $2.5 \mathrm{~mm}$ in a quantity of $6 \%$; fractions from 2.5 to 1.25 in a quantity of $29 \%$; fractions from 1.25 to 0.63 in a quantity of $29 \%$; fractions from 0.63 to $0.315 \mathrm{~mm}$ in a quantity of $28 \%$; and fractions from 0.315 to $0.16 \mathrm{~mm}$ in a quantity of $7 \%$.

The use of fractioned rubber crumb enables us to obtain the necessary sound absorption since the large specific surface area of open pore walls contributes to the active conversion of sound vibration energy into thermal energy due to friction losses. The use 
of rubber crumb with larger grains significantly reduces the compressive strength of the developed material. The proposed grain composition of the rubber crumb was stated as a result of evaluating the strength and sound absorption properties of the material. The proposed composite is made from secondary resources, which contributes to the development of resource-and energy-saving technologies [41,42].

The gypsum-cement-pozzolan composition and the results of the sample tests are shown in Table 5.

Table 5. Compositions and properties of material based on gypsum-cement-pozzolan binder.

\begin{tabular}{|c|c|c|c|c|c|c|c|c|c|c|c|}
\hline \multirow{2}{*}{ No. } & \multirow{2}{*}{ Composition } & \multirow{2}{*}{ Mass, $\%$} & \multirow{2}{*}{ Average Density, $\mathrm{kg} / \mathrm{m}^{3}$} & \multicolumn{8}{|c|}{ Sound Absorption Coefficient at Frequencies, $\mathrm{Hz}$} \\
\hline & & & & 63 & 80 & 100 & 200 & 400 & 800 & 1000 & 2000 \\
\hline $\begin{array}{c}1 \\
\text { Reference }\end{array}$ & $\begin{array}{l}\text { semi-aqueous gypsum } \\
\text { Portland cement } \\
\text { superplasticizer } \\
\text { metakaolin } \\
\text { water }\end{array}$ & $\begin{array}{c}53.8 \\
14.0 \\
2.6 \\
1.3 \\
28.3\end{array}$ & 1012 & 0.31 & 0.31 & 0.33 & 0.39 & 0.39 & 0.43 & 0.43 & 0.48 \\
\hline 2 & $\begin{array}{c}\text { semi-aqueous gypsum } \\
\text { Portland cement } \\
\text { metakaolin } \\
\text { superplasticizer } \\
\text { rubber crumb of fraction } 5-2.5 \mathrm{~mm} \\
\text { rubber crumb of fraction } 2.5-1.25 \mathrm{~mm} \\
\text { rubber crumb of fraction } 1.25-0.63 \mathrm{~mm} \\
\text { rubber crumb of fraction } 0.63-0.315 \mathrm{~mm} \\
\text { rubber crumb of fraction } 0.315-0.16 \mathrm{~mm} \\
\text { water }\end{array}$ & $\begin{array}{c}35.5 \\
10.6 \\
1.3 \\
0.9 \\
1.255 \\
7.5 \\
6 \\
7.56 \\
7.56 \\
1.255 \\
26.51\end{array}$ & 478 & 0.49 & 0.49 & 0.57 & 0.57 & 0.57 & 0.62 & 0.67 & 0.70 \\
\hline
\end{tabular}

The proposed gypsum-cement-pozzolan composition allows us to increase the sound absorption coefficient, which rises from values of $0.31-0.48$ to values of $0.46-0.70$ in the studied frequency range in comparison with the composition without rubber crumbs. These results confirm the published data in [43], in which it was shown that the sound absorption coefficient of cement concretes with rubber crumbs increases at high frequencies.

Summarizing the results obtained and the previously published data of other authors one can conclude that the sound absorption coefficient of gypsum and cement composites rises significantly with the increase in amount of rubber crumb from used car tires and it depends less on the properties of this rubber crumb. The mechanical properties of gypsum and cement composites significantly depend on both the amount and the properties of the rubber crumb.

In paper [43] the sound absorption at the low $(63,125,250$ and $500 \mathrm{~Hz})$ and high $(1000$, 2000, 4000 and $5000 \mathrm{~Hz}$ ) frequencies of small-scale panels based on cement and rubber crumb was determined. Studies have shown good results for the sound absorption of the material with the higher rubber crumb amount $(15 \%)$. The sound absorption was evaluated for samples with different amounts of crumb rubber $(7.5 \%$ and $15 \%$ of the fine aggregate mass) and with four different grades of crumb rubber that was previously subjected to freezing and heating. The compositions contained Portland cement as well as local fine and coarse aggregates. The coarse aggregate was the limestone crumb with a maximum size of $20 \mathrm{~mm}$. It was shown that freezing and heating do not significantly affect the sound absorption of the samples.

Similar values of the sound absorption coefficient were obtained when evaluating the sound absorption of cement concrete based on rubber crumb [30]. The sound absorption coefficients were more than 0.5 for compositions with different water-to-cement ratios $(0.45,0.50$ and 0.55$)$ and the rubber crumb amount $(5.0 \%$ and $7.5 \%$ by fine aggregate mass) in the frequency range of 200-3000 Hz. The reduction in the compressive strength of samples with the crumb amount of 5\% and the water-to-cement ratio of 0.45 was $23-25 \%$ both in paper [30] and for composition No. 2. It should be noted that the reduction in the compressive strength of sample of composition No. 5, which differs in the grain composition of the rubber crumb, was only $13 \%$. 
In conclusion, in comparison with the results of other studies it can be noted that the values of compressive and tensile strength in bending are higher for samples with rubber crumb of improved grain composition. It is stated that the nature of the destruction of samples changes from brittle to plastic since the rubber crumb inside the material stretches and does not allow a sample to collapse quickly.

The field of the application of cement and gypsum sound-absorbing composites based on rubber crumb is quite extensive. For example, a gap of at least 20-30 mm should be left between the ceiling and the finishing row of groove-ridge gypsum boards when installing an interior wall. This gap is usually filled with mounting foam that reduces the sound insulation properties of the entire wall. The proposed composition of the gypsum composite can be used to fill this gap with the provision of sound insulation properties. In the case of the yield of the building foundation, the layer of the proposed gypsum composite can be deformed, which prevents cracking in the wall itself.

\section{Conclusions}

The development of eco-oriented technologies involving industrial waste products is of particular relevance. It should be noted that the most significant amount of waste is accounted for by used tires. The developed compositions can be used in the production of sound-absorbing partition walls and panels, and sound-absorbing mortars for internal and external parts of buildings. The gypsum-cement-pozzolan composition was developed with semi-aqueous gypsum, Portland cement, metakaolin, superplasticizer Melment F15G, fractioned rubber crumbs in the amount of $6 \%$ of the fraction from 5 to $2.5 \mathrm{~mm}, 29 \%$ of the fractions from 2.5 to 1.25 , from 1.25 to 0.63 , from 0.63 to $0.315 \mathrm{~mm}$ and $7 \%$ of the fraction from 0.315 to $0.16 \mathrm{~mm}$ and water. The proposed composition of the material contributes to an increase in the sound absorption coefficient from values of $0.31-0.48$ to values of $0.46-0.70$ in the studied frequency range in comparison with the control samples without rubber crumbs. This gypsum composite can be used to fill the gap between the ceiling and the finishing row of groove-ridge gypsum boards with the provision of sound insulation properties of wall.

The proposed grain composition of rubber crumb improves not only the sound absorption coefficient but also the mechanical properties. A decrease in strength is observed with an increase in rubber crumb amount. However, the reduction in the compressive strength of the samples with the crumb of the initial grain composition in the amount of $5 \%$ and the water-to-cement ratio of 0.45 was $23-25 \%$, and the reduction in compressive strength for the sample with the crumb of the proposed grain composition was only $13 \%$.

The cement composite with a rubber crumb as a fine aggregate and without sand is the most effective of the studied materials in terms of sound-absorbing properties, but at the same time a decrease in strength characteristics is observed. The use of fractionated rubber crumb allows us to obtain the necessary sound absorption with a less pronounced decrease in strength characteristics. The proposed grain composition of the rubber crumb was determined as a result of evaluating the strength and sound-absorbing properties of the material.

Author Contributions: Conceptualization, O.M.S. and I.M.P.d.N.; methodology, O.M.S. and I.M.P.d.N.; software, V.R.M.; validation, V.R.M. and N.S.S.; formal analysis, O.M.S. and I.M.P.d.N.; investigation, V.R.M., O.I.K. and N.S.S.; resources, I.M.P.d.N.; data curation, O.M.S.; writing-original draft preparation, O.M.S. and I.M.P.d.N.; writing-review and editing, V.R.M., O.I.K., N.S.S. and O.M.S.; visualization, V.R.M., O.I.K. and N.S.S.; supervision, I.M.P.d.N. All authors have read and agreed to the published version of the manuscript.

Funding: This research received no external funding.

Institutional Review Board Statement: Protocol of the Faculty of Construction No. 9 dated 2 July 2021, Saint-Petersburg Mining University.

Informed Consent Statement: Informed consent was obtained from all subjects involved in the study. 
Data Availability Statement: Data is contained within the article.

Conflicts of Interest: The authors declare no conflict of interest.

\section{References}

1. Zhao, C.; Wang, P.; Wang, L.; Liu, D. Reducing railway noise with porous sound-absorbing concrete slabs. Adv. Mater. Sci. Eng. 2014, 2014, 206549. [CrossRef]

2. Setunge, S.; Gamage, N. Application of Acoustic Materials in Civil Engineering. In Acoustic Textiles; Springer: Singapore, 2016; pp. 165-183.

3. Yoon, J.Y.; Pyo, S. A Review of Mitigation Measures for Reducing Railway Rolling Noise from an Infrastructure Point of View. Int. J. Railw. 2019, 12, 1-9. [CrossRef]

4. Bušić, R.; Miličević, I.; Šipoš, T.K.; Strukar, K. Recycled rubber as an aggregate replacement in self-compacting concrete-Literature overview. Materials 2018, 11, 1729. [CrossRef] [PubMed]

5. Kazanskaya, L.F.; Isakovsky, V.I.; Fadeeva, S.A. Technological Properties of Self-Compacting Concrete Mixtures with Ground Quartz Sand. Int. J. Innov. Technol. Explor. Eng. 2019, 8, 799-803.

6. Smirnova, O.M. Technology of Increase of Nanoscale Pores Volume in Protective Cement Matrix. Int. J. Civ. Eng. Technol. 2018, 9, 1991-2000.

7. Berardi, U.; Iannace, G. Predicting the sound absorption of natural materials: Best-fit inverse laws for the acoustic impedance and the propagation constant. Appl. Acoust. 2017, 115, 131-138. [CrossRef]

8. Alabdulkarem, A.; Ali, M.; Iannace, G.; Sadek, S.; Almuzaiqer, R. Thermal analysis, microstructure and acoustic characteristics of some hybrid natural insulating materials. Constr. Build. Mater. 2018, 187, 185-196. [CrossRef]

9. Berardi, U.; Iannace, G.; Di Gabriele, M. The acoustic characterization of broom fibers. J. Nat. Fibers 2017, 14, 858-863. [CrossRef]

10. Kazanskaya, L.; Privalov, N.; Privalova, S. Fine ground granulated blast furnace slag for saving quantity of binder. E3S Web Conf. 2019, 110, 01055. [CrossRef]

11. Amran, M.; Fediuk, R.; Vatin, N.; Lee, Y.H.; Murali, G.; Ozbakkaloglu, T.; Alabduljabber, H. Fibre-Reinforced Foamed Concretes: A Review. Materials 2020, 13, 4323. [CrossRef]

12. Galyamichev, A.V.; Kirikova, V.A.; Gerasimova, G.E.; Sprince, A. Bearing capacity of facade systems fixing to sandwich panels. Mag. Civ. Eng. 2018, 78, 30-46.

13. Iannace, G.; Ciaburro, G. Modelling sound absorption properties for recycled polyethylene terephthalate-based material using Gaussian regression. Build. Acoust. 2020, 28, 185-196. [CrossRef]

14. Shishkin, A.; Bumanis, G.; Irtiseva, K.; Ozolins, J.; Korjakins, A. Clay Ceramic Hollow Sphere-Cement Syntactic Foam Composite for Building Applications. Key Eng. Mater. 2019, 800, 228-234. [CrossRef]

15. Vaganov, V.; Popov, M.; Korjakins, A.; Šahmenko, G. Effect of CNT on microstructure and minearological composition of lightweight concrete with granulated foam glass. Procedia Eng. 2017, 172, 1204-1211. [CrossRef]

16. Shangina, N.; Pukharenko, Y.; Kharitonov, A.; Kharitonova, T. Dry mixes for the restoration: Basic principles of design. MATEC Web Conf. 2017, 106, 03021. [CrossRef]

17. Kostyuk, T.; Vinnichenko, V.; Borziak, O.; Iefimenko, A. Physicochemical studies of the structure of energy-saving compositions based on slags. IOP Conf. Ser. Mater. Sci. Eng. 2021, 1021, 012016. [CrossRef]

18. Plugin, A.A.; Palant, O.; Plugin, D.; Miroshnichenko, S. Influence of Structural Characteristics on Concrete Strength under Dynamic Effects. Mater. Sci. Forum 2019, 968, 368-379. [CrossRef]

19. Ochkurov, V.I.; Vilenskii, M.Y. Comparative evaluation of the saving of binder with fine ground slag. IOP Conf. Ser. Mater. Sci. Eng. 2019, 666, 012026. [CrossRef]

20. Mechtcherine, V.; Grafe, J.; Nerella, V.N.; Spaniol, E.; Hertel, M.; Füssel, U. 3D-printed steel reinforcement for digital concrete construction-Manufacture, mechanical properties and bond behaviour. Constr. Build. Mater. 2018, 179, 125-137. [CrossRef]

21. Secrieru, E.; Fataei, S.; Schröfl, C.; Mechtcherine, V. Study on concrete pumpability combining different laboratory tools and linkage to rheology. Constr. Build. Mater. 2017, 144, 451-461. [CrossRef]

22. Izotova, V.; Petrov, D.; Pankratova, K.; Pospehov, G. Research of Acoustic Characteristics and Physical and Mechanical Properties of Quaternary Soils. In Engineering and Mining Geophysics 2020; European Association of Geoscientists \& Engineers: Houten, The Netherlands, 2020; pp. 1-7.

23. Li, H.; Jiang, H.; Zhang, W.; Liu, P.; Wang, S.; Wang, F.; Yao, Z. Laboratory and field investigation of the feasibility of crumb rubber waste application to improve the flexibility of anti-rutting performance of asphalt pavement. Materials 2018, 11, 1738. [CrossRef]

24. Bazhin, V.Y.; Brichkin, V.N.; Sizyakov, V.M.; Cherkasova, M.V. Pyrometallurgical treatment of a nepheline charge using additives of natural and technogenic origin. Metallurgist 2017, 61, 147-154. [CrossRef]

25. Bazhin, V.Y.; Feshchenko, R.Y.; Ramana, G.V.; Shabalov, M.Y. Extreme low-grade coal treatment coupled with X-ray testing. CIS Iron Steel Rev. 2016, 11, 4-8. [CrossRef]

26. Benin, A.V.; Semenov, A.S.; Semenov, S.G.; Beliaev, M.O.; Modestov, V.S. Methods of identification of concrete elastic-plasticdamage models. Mag. Civ. Eng. 2018, 77, 279-297.

27. Petrov, D.; Chistyakova, T.; Charykov, N. Computer System of Visual Modeling in Design and Research of Processes of Carbon Nanocluster Compounds Synthesis. Cyber-Phys. Syst. Des. Appl. Ind. 2021, 342, 181. 
28. Lavagna, L.; Nisticò, R.; Sarasso, M.; Pavese, M. An Analytical Mini-Review on the Compression Strength of Rubberized Concrete as a Function of the Amount of Recycled Tires Crumb Rubber. Materials 2020, 13, 1234. [CrossRef] [PubMed]

29. Li, Y.; Zhang, S.; Wang, R.; Dang, F. Potential use of waste tire rubber as aggregate in cement concrete-A comprehensive review. Constr. Build. Mater. 2019, 225, 1183-1201. [CrossRef]

30. Ghizdăveț, Z.; Ștefan, B.M.; Nastac, D.; Vasile, O.; Bratu, M. Sound absorbing materials made by embedding crumb rubber waste in a concrete matrix. Constr. Build. Mater. 2016, 124, 755-763. [CrossRef]

31. Nagar, K.R. Comparative Study on Acoustical Behavior of Cement Mortar using Sound-Absorbing Materials. Int. J. Appl. Eng. Res. 2019, 14, 3503-3507.

32. Kalauni, K.; Pawar, S.J. A review on the taxonomy, factors associated with sound absorption and theoretical modeling of porous sound absorbing materials. J. Porous Mater. 2019, 26, 1795-1819. [CrossRef]

33. Nowoświat, A.; Bochen, J.; Dulak, L.; Żuchowski, R. Study on Sound Absorption of Road Acoustic Screens under Simulated Weathering. Arch. Acoust. 2018, 43, 323-337.

34. Arjunan, A. Acoustic absorption of passive destructive interference cavities. Mater. Today Commun. 2019, 19, 68-75. [CrossRef]

35. Kim, H.; Hong, J.; Pyo, S. Acoustic characteristics of sound absorbable high performance concrete. Appl. Acoust. 2018, 138, 171-178. [CrossRef]

36. Quan, M.; Li, Y.X.; Chen, W.T. Research on Railway Cementitious Sound-absorbed Barrier Prepared by Slag Aggregate. China Concr. Cem. Prod. 2017, 1, 22.

37. Yoshida, T.; Ueda, Y.; Mori, N.; Matano, Y. An Experimental Study of the Performance of a Crossed Rib Diffuser in Room Acoustic Control. Appl. Sci. 2021, 11, 3781. [CrossRef]

38. Stankevicius, V.; Skripkiunas, G.; Grinys, A.; Miskinis, K. Acoustical characteristics and physical-mechanical properties of plaster with rubber waste additives. Mater. Sci. 2007, 13, 304-309.

39. Lapkovskis, V.; Mironovs, V.; Kasperovich, A.; Myadelets, V.; Goljandin, D. Crumb Rubber as a Secondary Raw Material from Waste Rubber: A Short Review of End-Of-Life Mechanical Processing Methods. Recycling 2020, 5, 32. [CrossRef]

40. Shishkin, E.V.; Kazakov, S.V. Vibration cone crusher for disintegration of solid materials. IOP Conf. Ser. Earth Environ. Sci. 2018, 194, 032027. [CrossRef]

41. Litvinenko, V.S.; Dvoynikov, M.V. Methodology for determining the parameters of drilling mode for directional straight sections of well using screw downhole motors. J. Min. Inst. 2020, 241, 105-112. [CrossRef]

42. Niu, C.; Liu, Y.; Shang, D.; Zhang, C. Noise Reduction Effect of Superhydrophobic Surfaces with Streamwise Strip of Channel Flow. Appl. Sci. 2021, 11, 3869. [CrossRef]

43. Holmes, N.; Browne, A.; Montague, C. Acoustic properties of concrete panels with crumb rubber as a fine aggregate replacement. Constr. Build. Mater. 2014, 73, 195-204. [CrossRef] 